\title{
Pre-Extension Demonstration of Low-Cost Family Drip Irrigation versus Furrow Irrigation for Improving Livelihood of Small-Scale Farmers in Southern Tigray
}

\author{
Yemane Mebrahtu $^{1 *} \quad$ Ahmmed Mohammed ${ }^{2}$ \\ 1. Department Irrigation and Drainage, Ethiopian Institute of Agricultural Research (EIAR), Mekhoni \\ Agricultural Research Centre, Ethiopia \\ 2. Department Irrigation and Drainage, Ethiopian Institute of Agricultural Research (EIAR), Assosa Agricultural \\ Research Centre, Ethiopia
}

\begin{abstract}
Irrigated agriculture plays a major role in food security, producing nearly 40 percent (\%) of food and agricultural commodities. Well-organized use of water is seen as a key to crop production in semi-arid and arid areas of Ethiopia. For smallholder farmers, low-cost drip irrigation systems provide a means of maximizing return on their cropland by increasing the agricultural productivity per unit of land; and through increasing cropping intensity during the dry season. Pre-extension of low-cost and appropriate micro-irrigation system had been designed and carried out in Ofla district, Fala kebelle to create awareness for smallholder farmers about yield optimizing technologies like drip irrigation and to offers a viable opportunity for sustainably increasing household income through the use of low-cost drip irrigation. A family drip irrigation and surface irrigation system have been used for the pre demonstration and a Mareko Fana pepper variety was undertaken. The result indicated drip irrigation method saved $43.42 \%$ water and gave $32.2 \%$ more yield as compared to that of surface irrigation system in the demonstrated district. And higher water productivity about $4.36 \mathrm{~kg} / \mathrm{m}^{3}$ was obtained in drip irrigation method; whereas lower productivity was obtained in surface irrigation system. drip irrigation system was working satisfactorily according to its design and farmer, development agents and woreda expert have positively perceived in drip irrigation as compared to surface irrigation system.
\end{abstract}

Keywords: Pre-demonstration, Drip irrigation, Surface system, Pepper, Water productivity, Farmer

DOI: $10.7176 / \mathrm{JEES} / 11-2-02$

Publication date: February $28^{\text {th }} 2021$

\section{INTRODUCTION}

Water is essential substance for sustaining life on the earth. Its consumption by the agriculture sector continues to dominant the overall requirements of water. More over the increasing population, urbanization and unsustainable consumption of water have further imposed the greater demands on water in arid and semi regions of the. Thus, it becomes indispensable to properly manage water at all levels in order to fulfil their food requirement.

According to (Awulachew et al., 2007), "Ensuring food security in areas with a high-population pressure and fragile resource conditions such as the semi-arid highlands of Ethiopia represents a great deal of challenge. One of the challenges is to alleviate the most limiting factors to crop production: moisture stress and soil fertility problems. The national policy on development and food-security and the research and extension support should therefore give due attention to these problems. Increasing agricultural productivity in Ethiopia is a means both to improve the livelihoods of rural people and the sustainability of the economy." Poor performance of agricultural sector, mainly due to erratic and uncertain rainfall, as well as poor water management strategies make the rural household of the country no to withstand the declines in their income.

Drip irrigation is an irrigation method whereby small quantities of water drip directly to the root zone of crops through a network of plastic pipes, valves, emitters or drippers, and Drip irrigation is an irrigation method whereby small quantities of water drip directly to the root zone of crops through a network of plastic pipes, valves, emitters or drippers, and ancillary devices (Venot et al., 2014). Drip irrigation technology is said to improve yields and irrigation efficiency (Postel, 1999), notably by maximizing irrigation uniformity and minimizing water deliveries (Keller \& Roberts, 2004). Research and development efforts on drip irrigation have long been driven by a search to optimize and better adjust irrigation delivery to crop water demands and the notion of efficiency (van der Kooij et al., 2013; Venot et al., 2014).

In the semi-arid areas of Ethiopia, water is the most limiting factor for crop production. In these areas where the amount and distribution of rainfall is not sufficient to sustain crop growth and development, an alternative approach is to make use of the rivers and underground water for irrigation. Satisfying crop water requirements, although it maximizes production from the land unit, does not necessarily maximize the return per unit volume of water (Oweis et al, 2000).

Therefore, in an effort to improving water productivity, there is an increasing interest in judicious application of irrigation water, an irrigation practice which controls the spatial and temporal supply of water so as to promote 
growth and yield, and to enhance the economic efficiency of crop production.

The study was conducted with the objectives to promotion and establish a family drip irrigation as a household, to create awareness for smallholder farmers about yield optimizing technologies like drip irrigation and to offers a viable opportunity for sustainably increasing household income through the use of low-cost drip irrigation.

\section{METHODOLOGIES AND APPROACHES}

\subsection{Description of the Demonstration Site}

The study was conducted in Ofla district, Fala kebel, of the Southern Zone of Tigray region $16 \mathrm{~km}$ far away from the district. One representative kebele was purposely selected from each district. Six voluntary farmers were randomly selected.

Geographically the experimental site is located at $12^{\circ} 29^{\prime} 37^{\prime \prime}$ North Latitude and $39^{\circ} 23^{\prime} 47^{\prime \prime}$ East Longitude with an altitude of $2549 \mathrm{~m}$.a.s.l. The site has with an average minimum and maximum temperature of 13 and $20^{\circ} \mathrm{C}$, respectively. The soil textural class of the experimental area is silty.

\subsection{Methodology}

Based on their willingness and interest the kebele the demonstration was under taken in farmer training center (FTC). Intensive orientation was given to update the farmers' and development agent (DA) knowledge and skills related to agronomic practice, protection, weed management and installation of drip irrigation. Pepper with Mareko Fana verities was used for the demonstration trials.

Two treatment, family drip irrigation and surface irrigation were used to demonstrate the trail. A family drip irrigation which consist of water source (Tanker), control valve, filter, water pipe lines (mainline and sub-mainline), lateral lines and emitters and connected to each other as listed the parts respectively to operate the system. The system had been installed on well prepared fields of $25 \mathrm{~m}$ length, and $20 \mathrm{~m}$ width or $500 \mathrm{~m}^{2}$ areas and the spacing between lateral and emitter were $0.6 \mathrm{~m}$ and $0.4 \mathrm{~m}$ respectively to grow Pepper. All agronomic practices were applied uniformly for the two type of irrigation methods i.e Surface and drip irrigation methods as per standard recommendations for the crop. Farmers' field day was organized and held to promote and collect opinion of farmers on each irrigation methods.

\subsection{Platform and communication media for farmers/ users}

At appropriate time different forums and field days were organized for the stake holder to enhance the dissemination of irrigation technology and monitoring and evaluation were also carried out by the stakeholders on regular basis, and the effectiveness of the implementation procedures and the impacts it has made was assessed.

\subsection{Data collected}

Both data were collected and analyzed in this particular investigation. All research on station agronomic data, Yield data and farmers' perception at the maturity stage were collected and analyzed.

\subsection{Data Analysis}

A simple expressive statistic was used to analyze the yield and farmers' perception data through frequency and tabular forms. Yield data and farmers' perception at the maturity stage were used in this analysis.

\section{RESULTS AND DISCUSSION}

As showed in table 1, the highest plant height of pepper was observed from drip irrigation $(51.5 \mathrm{~cm})$. In the other hand, surface irrigation systems were recorded lower plant height. The highest marketable fruit yield of pepper was recorded from drip irrigation (18.89 ton/ha) whereas, surface irrigation systems were observed lower fruit yield of pepper (table 2). Drip irrigation was obtained higher water productivity as compared to surface irrigation system. Water application is less labour demanding in drip irrigation compared to surface irrigation. The family drip application kit is mostly implemented in the garden by which females can easily managed and once they filled it, they have extra time for managing other activities.

Table 1: Pepper Plant height, Number of clusters per plant, Number of branches per plant, Fruit length, fruit diameter, Marketable fruit yield and Water productivity of pepper drip irrigation versus furrow irrigation at Ofla district

\begin{tabular}{lllllllll}
\hline No & $\begin{array}{l}\text { Irrigation } \\
\text { Methods }\end{array}$ & Ph(cm) & $\begin{array}{l}\text { Number } \\
\text { of } \\
\text { Cluster }\end{array}$ & $\begin{array}{l}\text { No of } \\
\text { branch }\end{array}$ & $\begin{array}{l}\text { Fruit } \\
\text { Length } \\
\text { (cm) }\end{array}$ & $\begin{array}{l}\text { Fruit } \\
\text { Diameter } \\
\text { (cm) }\end{array}$ & $\begin{array}{l}\text { MFY } \\
\text { (ton/ha) }\end{array}$ & WP \\
\hline 1 & Drip Irrigation & 51.5 & 3.3 & 17.2 & 8.7 & 2.9 & 18.96 & 4.36 \\
2 & Surface Irrigation & 42.5 & 2.855 & 16 & 6.5 & 2.4 & 14.303 & 3.04 \\
\hline Average & $\mathbf{4 7}$ & $\mathbf{3 . 0 7 7 5}$ & $\mathbf{1 6 . 6}$ & $\mathbf{7 . 6}$ & $\mathbf{2 . 6 5}$ & $\mathbf{1 6 . 6 3 1 5}$ & $\mathbf{3 . 7}$ \\
\hline
\end{tabular}




\subsection{Yield and yield parameter in drip irrigation versus surface irrigation}

Plant height, fruit length and yield of pepper under drip and surface irrigation systems are plotted in Figure 1. It is obvious from Figure 1 that higher plant height; fruit length and marketable yield of pepper were recorded under drip irrigation as compared surface irrigation method. As the figure shows that, Highest yield of pepper 18.96 ton/ha were recorded from drip irrigation. In the other hand, surface irrigation was recorded lower yield of pepper 14.3 ton/ha as compared drip irrigation. The result was showed that drip irrigation $32.6 \%$ more advantage than surface irrigation. These results suggest that total yield of pepper under drip irrigation system was more as compared to surface irrigation system.

\section{Drip irrigation versus surface irrigation}

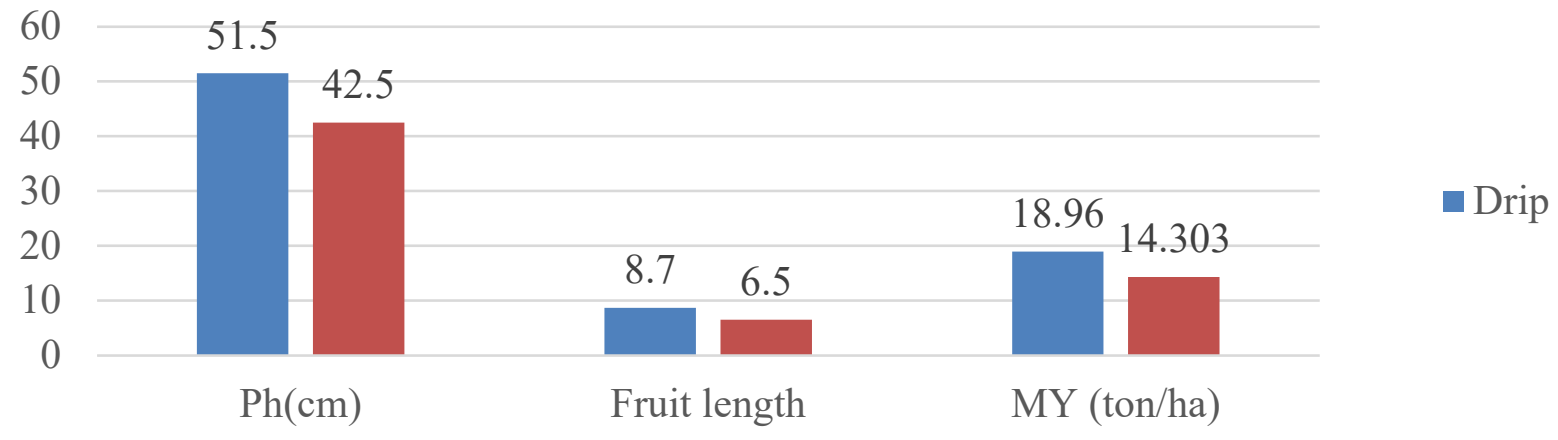

Fig. 1 Plant height, fruit length and yields of crop in drip over surface irrigation

\subsection{Water saving in drip versus surface irrigation system}

Drip irrigation method saved $43.42 \%$ water and gave $32.2 \%$ more yield as compared to that of surface irrigation system as shown in fig.2. Likewise, higher water productivity about $4.36 \mathrm{~kg} / \mathrm{m}^{3}$ was obtained in drip irrigation method; whereas lower water productivity about $3.04 \mathrm{~kg} / \mathrm{m}^{3}$ was obtained in surface irrigation method as presented in Fig 2. This may be because in drip irrigation method water is applied directly in the root zone of crop. Hence conveyance, evaporation and percolation losses reduced to larger extent in drip irrigation as compared to surface irrigation system. Studies revealed that, drip irrigation increased the yield of tomato and water use efficiency (WUE) by 19 and 20\% (Fekadu and Teshome, 1997) as compared to furrow irrigation; and others found it significantly reduced the irrigation water requirement of a crop as it supply water only to root zone of the crop (Bogle, 1986; Raina et al.,1998).

\section{$\mathrm{WP}(\mathrm{m} 3 / \mathrm{ha})$}

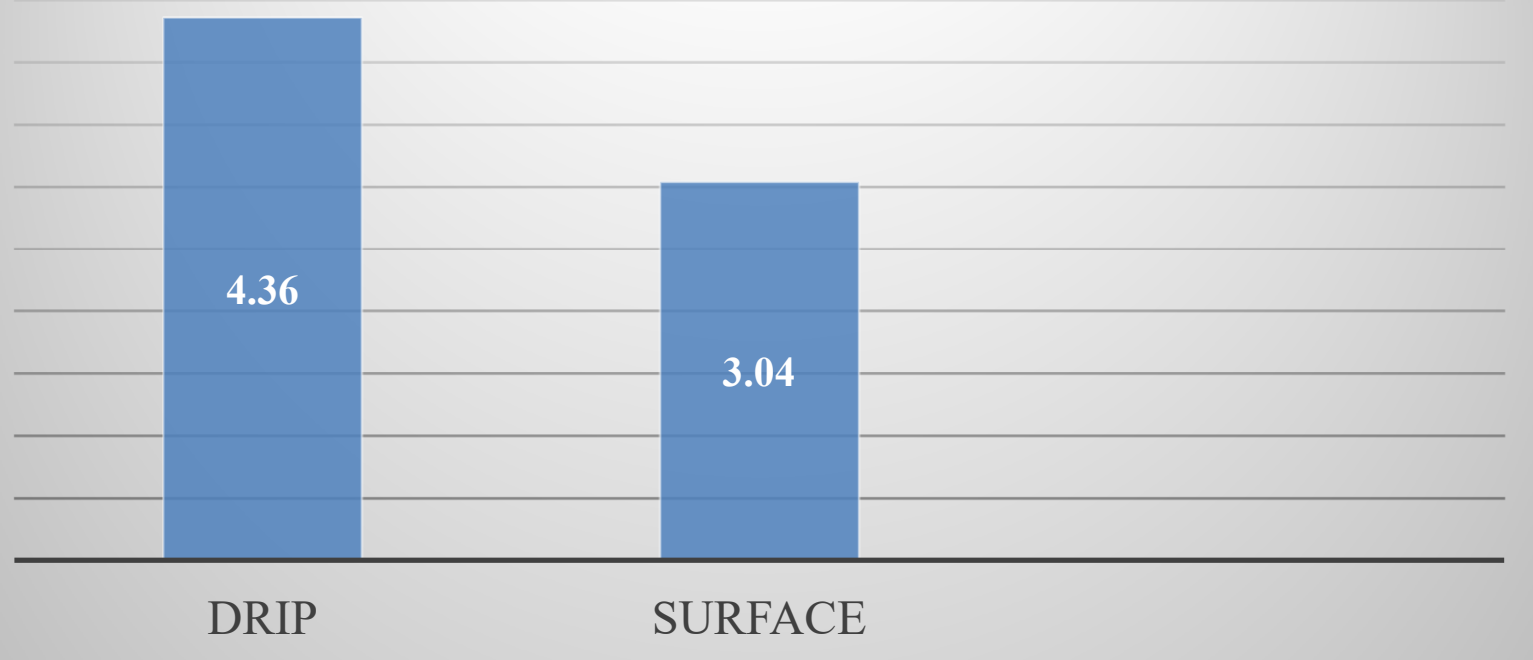

Fig. 2 Water productivity in drip over f irrigation system 


\subsection{Field Day and farmers perception}

A field day were held on a field at the Fala kebelle Farmer training center (FTC). The field day were organized by the AGP II and Mekhoni agricultural research center, with cooperation with the district experts.

Representative farmers, development agent (DAs) and woreda experts were participated in the field days and a few hours of presentations about the pre extension were gave to the participants, and then visits to the fields.

Furthermore, farmers, development agents and expert perception towards the drip was also assessed based on performance obtaining the technologies and their ease of operation that over $91.8 \%$ said they are affordable and $81 \%$ reported their management is simple and can be handled with training for the farmers (Table 2).

Table 2: Perception of farmers and expert opinion on low-cost drip irrigation system

\begin{tabular}{|c|c|c|c|c|}
\hline \multirow[t]{2}{*}{ Groups/stakeholders } & \multicolumn{2}{|c|}{$\begin{array}{c}\text { Number of } \\
\text { participants }\end{array}$} & \multicolumn{2}{|c|}{ Assessment parameters } \\
\hline & Male & Female & Affordability & Technical knowhow \\
\hline Farmer & 18 & 7 & Affordable $(\mathrm{n}=23)$ & Easy to use $(n=18)$ \\
\hline Das & 2 & 2 & Affordable $(n=3)$ & Easy to use $(n=3)$ \\
\hline Woreda expert & 3 & - & Affordable $(n=3)$ & Easy to use $(n=2)$ \\
\hline Woreda AGP II focal person & 1 & - & Affordable $(n=1)$ & Easy to use $(n=1)$ \\
\hline Researcher & 4 & - & Affordable $(n=4)$ & Easy to use $(n=4)$ \\
\hline Total & 28 & 9 & Affordable $(91.8 \%)(n=34)$ & Easy to use $81 \%(n=27)$ \\
\hline
\end{tabular}

\section{CONCLUSION AND RECOMMENDATION}

Water saving irrigation technologies need to be tested under local environments and particular agricultural production systems. Drip irrigation was found increased fruit yield of pepper and improved water productivity due to consumption of less water.

From the study the following conclusions and suggestions were drawn from the present study:

$\checkmark$ The drip irrigation system was working satisfactorily according to its design and farmer, development agents and woreda expert have positively perceived in drip irrigation as compared to surface irrigation system.

$\checkmark \quad$ Drip irrigation method saved $43.42 \%$ water and gave $32.2 \%$ more yield as compared to that of surface irrigation system in the demonstrated district.

$\checkmark$ Higher water productivity about $4.36 \mathrm{~kg} / \mathrm{m}^{3}$ was obtained in drip irrigation method; whereas lower productivity was obtained in surface irrigation system.

As this study reveals, drip irrigation system is found effective in water saving in the district and similar agroecology; especially for producing high value crops (pepper, onion, tomato etc) which have high return per plot of land and per drop of water during off-season

\section{SUGGESTIONS}

In the present study drip irrigation method gave overall better performance with respect to water saving, increase in yield and water use efficiency. Therefore, present study suggests farming community to adopt drip irrigation method instead of old traditional flooding methods.

\section{ACKNOWLEDGEMENT}

The authors are grateful to Agricultural Growth Program (AGP II) and Ethiopian Institute of Agricultural Research for providing funds for the pre- demonstration and technical support. The authors also very grateful to Mekhoni Agricultural research centre for all staff of Natural Resources Management Research core process for giving us support in field management, suggestion and technical guidance during the conducting of the pre demonstration.

\section{REFERENCE}

Awulachew, S.B, Yilma, A.D, Loulseged, M, Loiskandl, W, Ayana, M and Alamirew, T. 2007. Water Resources and Irrigation Development in Ethiopia”, Working Paper (123), International Water Management Institute, Colombo, Sri Lanka.

Bogle O, Hartz. 1986. Comparison of drip and furrow irrigation for Muskmelon production. Hortic. Sci., 21: 242244.

Fekadu Y and Teshome T. 1997. Effect of drip and furrow irrigation on the yield of tomato in Dire Dawa. Agriculture water Management 35, Alemaya University of Agriculture, Dire Dawa, Ethiopia.

Howell TA, and Hiler EA. 1974. Design of trickle irrigation laterals for uniformity. Journal of Irrigation and Drainage Division. ASCE 100IR4, Proc. Paper 10983. pp. 443-454.

Isaya,VS. 2001. Drip irrigation. Technical handbook No. 24. Published by SIDA Regional Land Management Unit (RELMA). 
Keller J, Roberts M. 2004. Household-level irrigation for efficient water use and poverty alleviation. Paper presented at the CARDI International Conference on Research on Water in Agricultural Production in Asia for the 21st Century, Phnom Penh, Cambodia.

Narayanamoorthy A. 1999. Drip irrigation for sustainable agriculture. Productivity 39(4):672 678.

Narayanamoorthy A and Deshpande RS. 1998. Economics of drip irrigation: A comparative study of Maharashtra and Tamil Nadu. Mimeograph Series No. 47. Agro-Economic Research Centre, Gokhale Institute of Politics and Economics, Pune, Maharashtra, India.

Oweis, T, Zhang H, Pala M. 2000. Water uses efficiency of rainfed and irrigated bread wheat in a Mediterranean environment. Agronomy Journal 92: 231-238

Postel S. 1999. Pillar of sand: Can the irrigation miracle last W.W. Norton and Co. New York, USA. 330pp.

Raina JN, Thakur BC, Bhandaria R. 1998. Effect of drip irrigation and plastic mulch on yield, water use efficiency and benefit-cost ratio of pea cultivation. Indian J. Soil Sci.

Van der Kooij, S, Zwarteveen, M, Boesveld, H, Kuper, M. 2013. The efficiency of drip irrigation unpacked. Agricultural Water Management, 123, 103-110. doi: 10.1016/j.agwat.2013.03.014.

Venot, J. P, Zwarteveen, M, Kuper, M, Boesveld H, Bossenbroek, L, Kooij, S. V. D, Wanvoeke, J, Benouniche M, Errahj, M and de Fraiture. 2014. Beyond the promises of technology: a review of the discourses and actors who make drip irrigation. Irrigation and Drainage, 63(2), 186-194. doi: 10.1002/ird.1839.

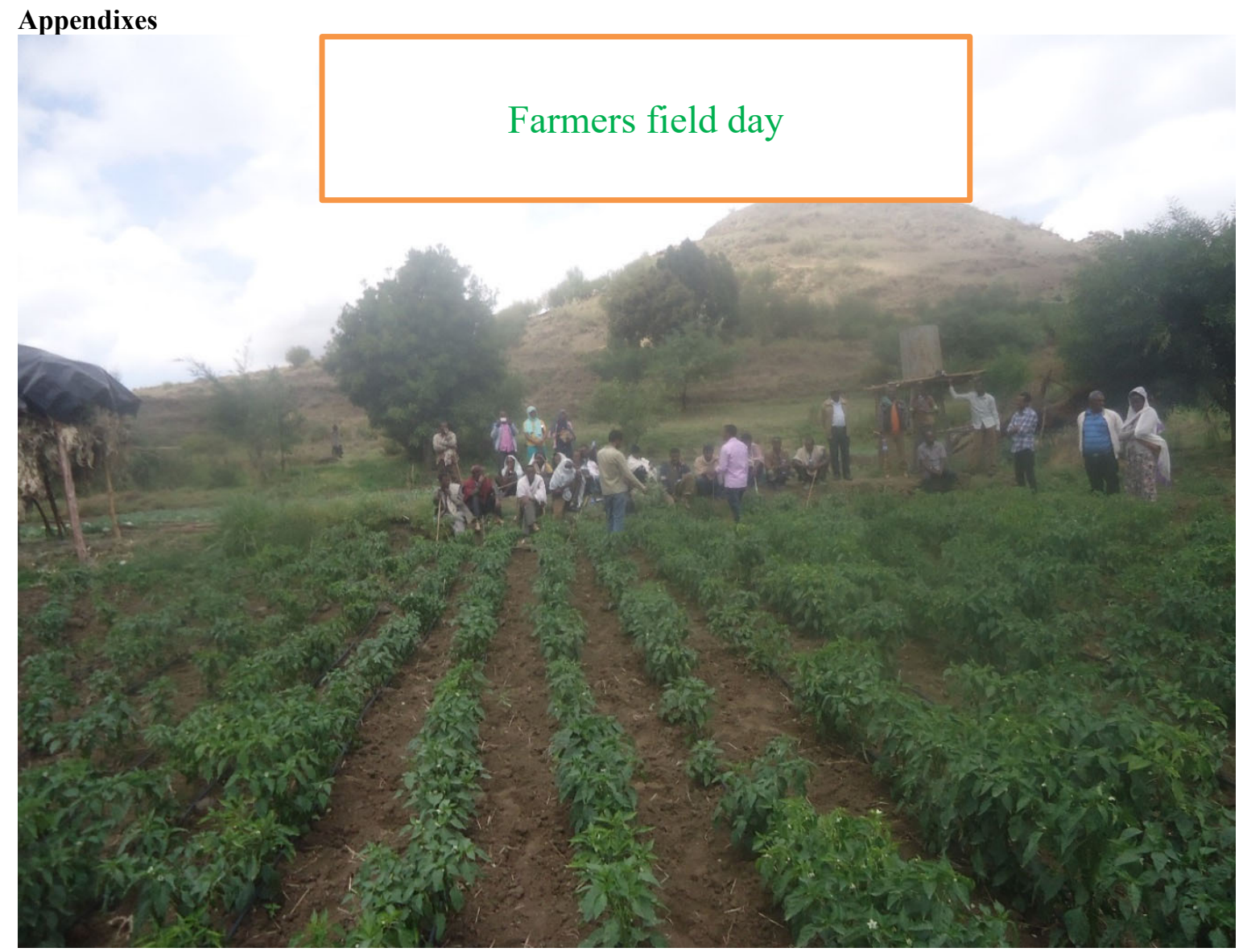



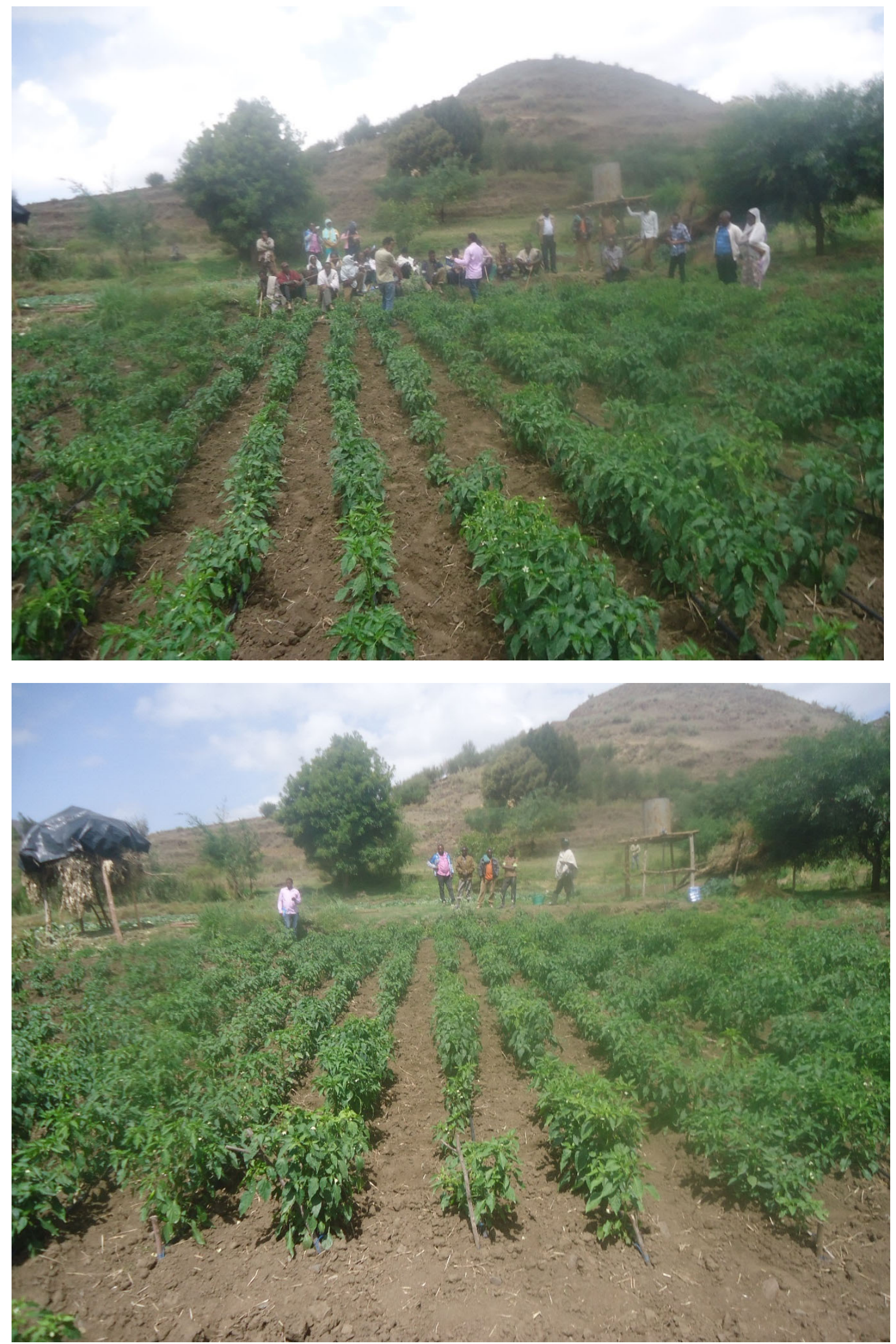


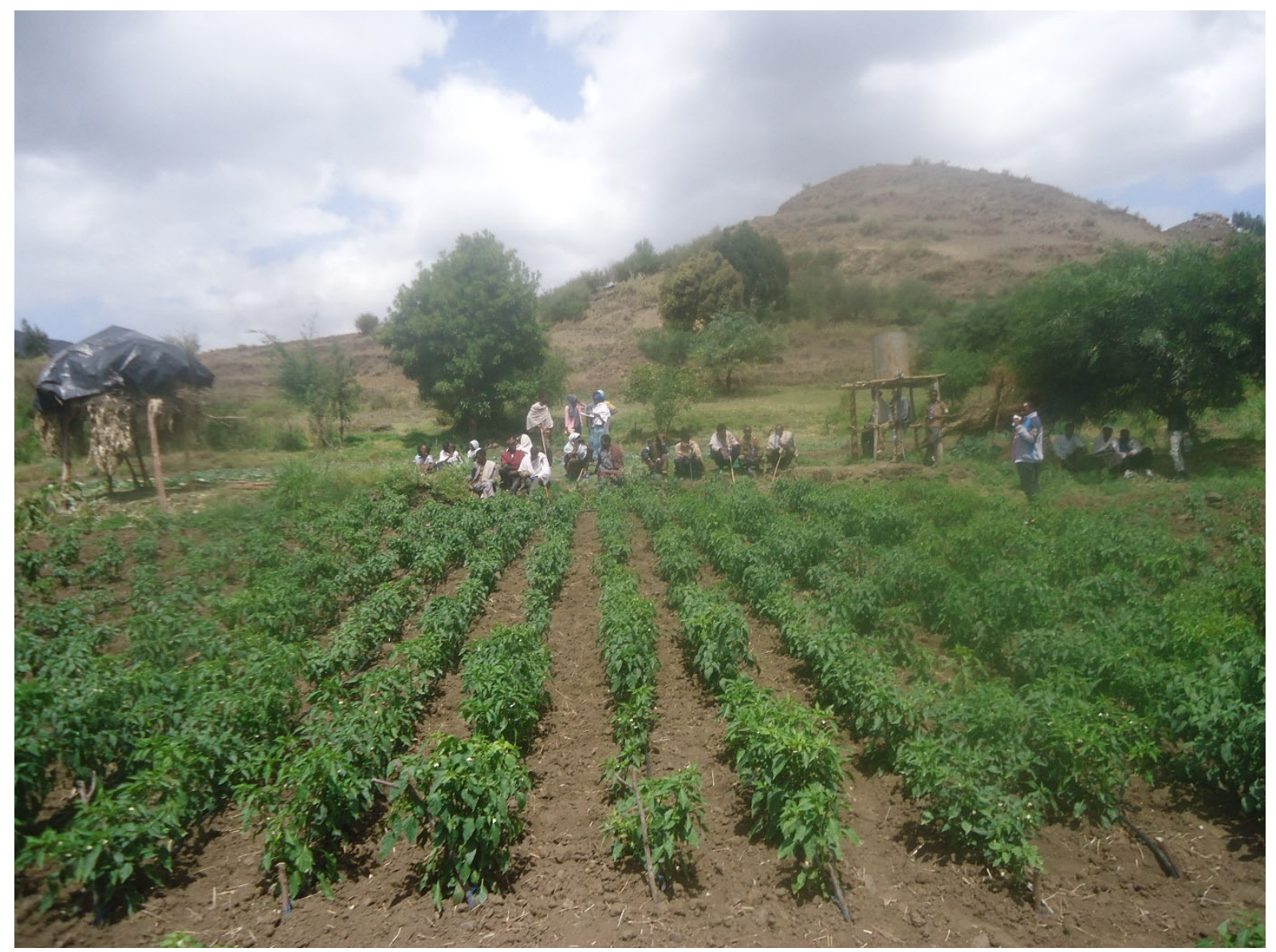

